\title{
SYNTHESIS, CHARACTERIZATION AND CRYSTAL STRUCTURE OF A POLYMERIC SILVER(I) COMPLEX WITH CYTOTOXIC PROPERTY
}

\author{
GANG-SEN LI*, HUA-LIN ZHANG \\ Key Laboratory of Surface \& Interface Science of Henan, School of Material \& Chemical Engineering, Zhengzhou University of Light Industry, \\ Zhengzhou 450002, P. R. China
}

\begin{abstract}
A new polymeric silver(I) complex, $\left[\mathrm{Ag}_{2}\left(\mathrm{~L}^{1}\right)_{2}\left(\mathrm{~L}^{2}\right)\left(\mathrm{OH}_{2}\right)\right]_{n}$, was obtained by the reaction of 3-aminopyrazine-2-carboxylic acid $\left(\mathrm{HL}^{1}\right)$, 2-amino-5-methylpyridine $\left(\mathrm{L}^{2}\right)$ and silver oxide in aqueous ammonia. The complex was characterized by elemental analysis, IR spectra and single crystal X-ray determination. The smallest repeat unit contains a $\left[\mathrm{Ag}_{2}\left(\mathrm{~L}^{1}\right)_{2}\left(\mathrm{~L}^{2}\right)\left(\mathrm{OH}_{2}\right)\right]$ moiety. The $\mathrm{Ag} \cdots \mathrm{Ag}$ distance is $7.490(2) \AA$. One $\mathrm{Ag}$ atom is coordinated by three pyrazine $\mathrm{N}$ and two carboxylate $\mathrm{O}$ atoms from four $\mathrm{L}^{1}$ ligands, forming a square pyramidal coordination, and the other one is coordinated by one pyrazine $\mathrm{N}$ and one carboxylate $\mathrm{O}$ atoms from a $\mathrm{L}^{1}$ ligand, one pyridine $\mathrm{N}$ atom from a $\mathrm{L}^{2}$ ligand, and one water $\mathrm{O}$ atom, forming a square planar geometry. In the crystal structure of the complex, the dinuclear silver moieties are linked through $\mathrm{L}^{1}$ ligands, to form $1 \mathrm{D}$ chains along the $x$-axis direction. The chains are further linked through intermolecular hydrogen bonds in the $y$ - and $z$-axis directions, forming a 3D network. In addition, there are $\pi \cdots \pi$ interactions among the chains. The complex showed effective cytotoxic property on human lung cancer cell line A549.
\end{abstract}

Keywords: Silver complex; Polymeric complex; 3-Aminopyrazine-2-carboxylate; 2-Amino-5-methylpyridine; Crystal structure; Cytotoxicity

\section{INTRODUCTION}

The compounds bearing both pyridine/pyrazine and carboxylate groups are a kind of interesting ligands for the coordination of silver, and such complexes have received particular attention in coordination chemistry ${ }^{1-5}$. Silver has versatile coordination numbers and geometries ${ }^{6-10}$. By varying the synthetic method, solvents, anions, and proportion of starting materials, one can construct different structures of silver complexes. But until now, one can not precisely predicates what structures will be finally formed for the silver complexes. So, more work needs to be carried out to understand the influence effects of such complexes. In addition, most silver complexes have shown interesting luminescence property ${ }^{11-13}$ and biological activities ${ }^{14-17}$. Lung cancer is one of the most common and life-threatening malignancies worldwide. The poor prognosis of lung cancer is largely attributed to the frequent occurrence of metastasis, since most metastatic tumours are unresectable at the time of presentation. The severe morbidity and poor prognosis of lung cancer highlight the importance of searching for new and effective agents against lung cancer ${ }^{18,19}$. It is notable that the cytotoxicity property of the silver complexes has received particular attention ${ }^{20-22}$. 3-Aminopyrazine-2-carboxylic acid $\left(\mathrm{HL}^{1}\right)$ is a hopeful ligand containing carboxylic group, amine and pyrazine nitrogen atoms. Some nickel, cobalt, mercury, zinc, manganese and lanthanide ${ }^{23-28}$ complexes derived from $\mathrm{HL}^{1}$ have been reported. However, no silver complex has been reported so far. In the present work, a new polymeric silver(I) complex, $\left[\mathrm{Ag}_{2}\left(\mathrm{~L}^{1}\right)_{2}\left(\mathrm{~L}^{2}\right)\right.$ $\left.\left(\mathrm{OH}_{2}\right)\right]_{\mathrm{n}}$, is presented. The aim was to investigate the anticancer effects of the complex on human lung cancer cell A549.

\section{EXPERIMENTAL}

Materials and Measurements: 3-Aminopyrazine-2-carboxylic acid, 2-amino-5-methylpyridine and silver oxide were purchased from Fluka and used as received. The solvents used were of reagent grade. Elemental analyses were carried out using a Perkin-Elmer 2400 II elemental analyser. The infrared spectrum was recorded on a Perkin-Elmer FT-IR spectrophotometer with a $\mathrm{KBr}$ disc. The X-ray diffraction was carried out on a Bruker SMART 1000 CCD area diffractometer at 298(2) K.

Synthesis of the complex. 3-Aminopyrazine-2-carboxylic acid ( $0.28 \mathrm{~g}, 2$ $\mathrm{mmol})$ and $\mathrm{Ag}_{2} \mathrm{O}(0.23 \mathrm{~g}, 1 \mathrm{mmol})$ were mixed and stirred in a $30 \%$ aqueous ammonia $(30 \mathrm{~mL})$. The mixture was stirred at room temperature until all solid dissolved. Then, to the mixture was added 2-amino-5-methylpyridine $(0.11 \mathrm{~g}$, $1 \mathrm{mmol})$. The final mixture was further stirred at dark for $30 \mathrm{~min}$. The clear colorless solution was kept still at room temperature in dark for several days, to give small block-like single crystals. Yield: $27 \%$. IR $\left(\mathrm{KBr}, \mathrm{cm}^{-1}\right): 3287 \mathrm{w}$, $1613 \mathrm{~s}, 1555 \mathrm{~s}, 1470 \mathrm{~s}, 1401 \mathrm{~m}, 1376 \mathrm{~m}, 1277 \mathrm{w}, 1236 \mathrm{w}, 1159 \mathrm{w}, 1120 \mathrm{w}, 1043 \mathrm{~m}$, 963m, 822s, 715m, 677w, 621w, 575m, 447w. Anal. Calcd. for $\mathrm{C}_{16} \mathrm{H}_{18} \mathrm{Ag}_{2} \mathrm{~N}_{8} \mathrm{O}_{5}$ : C, 31.09; H, 2.94; N, 18.13\%. Found: C, 31.23; H, 2.82; N, 17.97\%.
X-ray Crystallography: A suitable single crystal of the complex was mounted on the top of a glass fiber. Graphite-monochromatized Mo-K radiation $(\lambda=0.71073 \AA)$ and the $\omega$ scan technique were used to collect the diffraction data. Absorption correction was applied with SADABS ${ }^{29}$. The structure of the complex was solved with direct method and refined with a full-matrix least-squares technique with SHELXTL ${ }^{30}$. Anisotropic thermal parameters were applied to all non-hydrogen atoms. The hydrogen atoms of the amino groups were located from electronic density maps, with $\mathrm{N}-\mathrm{H}$ and $\mathrm{H} \cdots \mathrm{H}$ distances restrained to $0.90(1)$ and $1.43(2) \AA$, respectively. The other hydrogen atoms were generated geometrically. The crystallographic data and the details of the data collection and refinement for the complex are listed in Table 1. Selected bond lengths and angles are given in Table 2. Hydrogen bonding information is given in Table 3 .

Table 1. Crystallographic data for the complex

\begin{tabular}{|c|c|}
\hline Parameter & Value \\
\hline Empirical Formula & $\mathrm{C}_{16} \mathrm{H}_{18} \mathrm{Ag}_{2} \mathrm{~N}_{8} \mathrm{O}_{5}$ \\
\hline FW & 618.1 \\
\hline Crystal shape/colour & Block/colorless \\
\hline Crystal size $/ \mathrm{mm}$ & $0.15 \times 0.13 \times .12$ \\
\hline Crystal system & Monoclinic \\
\hline Space group & $P 2_{1} / n$ \\
\hline$\lambda(\mathrm{MoK \alpha}) / \AA$ & 0.71073 \\
\hline $\mathrm{T} / \mathrm{K}$ & $298(2)$ \\
\hline$\mu / \mathrm{mm}^{-1}(\mathrm{Mo}-K \alpha)$ & 2.058 \\
\hline \multicolumn{2}{|l|}{ Unit cell dimensions } \\
\hline$a / \AA ̊$ & $7.236(2)$ \\
\hline$b / \AA$ & $19.573(3)$ \\
\hline$c / \AA ̊$ & $14.168(3)$ \\
\hline$\beta /{ }^{\circ}$ & $103.571(3)$ \\
\hline$V / \AA^{3}$ & $1950.6(7)$ \\
\hline$Z$ & 4 \\
\hline$T_{\min }$ & 0.7477 \\
\hline$T_{\max }$ & 0.7903 \\
\hline
\end{tabular}




\begin{tabular}{|c|c|}
\hline No. of measured reflections & 9052 \\
\hline No. of unique reflections & 3141 \\
\hline No. of observed reflections $[I \geq 2 \sigma(I)]$ & 2500 \\
\hline data/restraints/parameters & $3141 / 12 / 305$ \\
\hline$R_{\text {int }}$ & 0.0349 \\
\hline$F(000)$ & 1216 \\
\hline Goodness of fit on $F^{2}$ & 1.063 \\
\hline$R_{1}, w R_{2}[I \geq 2 \sigma(I)]$ & $0.0427,0.1161$ \\
\hline$R_{1}, w R_{2}$ (all data) & $0.0777,0.1349$ \\
\hline
\end{tabular}

Table 2. Selected bond lengths $(\AA)$ and angles $\left(^{\circ}\right)$ for the complex.

\begin{tabular}{|c|c|c|c|}
\hline Bond & $d, \AA$ & Bond & $d, \AA$ \\
\hline $\operatorname{Ag}(1)-\mathrm{N}(1)$ & $2.301(5)$ & $\mathrm{Ag}(1)-\mathrm{N}(2 \mathrm{~A})$ & $2.330(5)$ \\
\hline $\mathrm{Ag}(1)-\mathrm{N}(5)$ & $2.494(5)$ & $\mathrm{Ag}(1)-\mathrm{O}(4 \mathrm{~B})$ & $2.621(5)$ \\
\hline $\mathrm{Ag}(1)-\mathrm{O}(1)$ & $2.611(5)$ & $\mathrm{Ag}(2)-\mathrm{N}(7)$ & $2.195(5)$ \\
\hline $\mathrm{Ag}(2)-\mathrm{N}(4)$ & $2.235(5)$ & $\mathrm{Ag}(2)-\mathrm{O}(3)$ & $2.580(5)$ \\
\hline $\mathrm{Ag}(2)-\mathrm{O}(5)$ & $2.582(6)$ & & \\
\hline $\mathrm{Angle}$ & $\omega, \mathrm{deg}$ & $\operatorname{Angle}$ & $\omega, \mathrm{deg}$ \\
\hline $\mathrm{N}(1) \operatorname{Ag}(1) \mathrm{N}(2 \mathrm{~A})$ & $150.3(2)$ & $\mathrm{N}(1)-\mathrm{Ag}(1)-\mathrm{N}(5)$ & $118.5(2)$ \\
\hline $\mathrm{N}(2 \mathrm{~A}) \operatorname{Ag}(1) \mathrm{N}(5)$ & $89.7(2)$ & $\mathrm{N}(1) \operatorname{Ag}(1) \mathrm{O}(1)$ & $66.9(2)$ \\
\hline $\mathrm{N}(2 \mathrm{~A}) \operatorname{Ag}(1) \mathrm{O}(1)$ & $102.3(2)$ & $\mathrm{N}(5) \operatorname{Ag}(1) \mathrm{O}(1)$ & $97.4(2)$ \\
\hline $\mathrm{N}(1) \operatorname{Ag}(1) \mathrm{O}(4 \mathrm{~B})$ & $91.4(2)$ & $\mathrm{N}(2) \operatorname{Ag}(1) \mathrm{O}(4 \mathrm{~B})$ & $101.4(2)$ \\
\hline $\mathrm{N}(5) \operatorname{Ag}(1) \mathrm{O}(4 \mathrm{~B})$ & $84.1(2)$ & $\mathrm{O}(1) \operatorname{Ag}(1) \mathrm{O}(4 \mathrm{~B})$ & $156.3(2)$ \\
\hline $\mathrm{N}(7) \operatorname{Ag}(2) \mathrm{N}(4)$ & $175.3(2)$ & $\mathrm{N}(7) \operatorname{Ag}(2) \mathrm{O}(3)$ & $106.8(2)$ \\
\hline $\mathrm{N}(4) \operatorname{Ag}(2) \mathrm{O}(3)$ & $68.8(2)$ & $\mathrm{N}(7) \operatorname{Ag}(2) \mathrm{O}(5)$ & $92.8(2)$ \\
\hline $\mathrm{N}(4) \operatorname{Ag}(2) \mathrm{O}(5)$ & $91.8(2)$ & $\mathrm{O}(3) \operatorname{Ag}(2) \mathrm{O}(5)$ & $158.6(2)$ \\
\hline
\end{tabular}

Symmetry codes: A: $-1+x, y, z ; \mathrm{B}: 1 / 2+x, 1 / 2-y, 1 / 2+z$.

Table 3. Hydrogen-bonding geometry $\left(\AA,{ }^{\circ}\right)$.

\begin{tabular}{|c|c|c|c|c|}
\hline$D-\mathrm{H} \cdots A$ & $\mathrm{H} \cdots A$ & $D \cdots A$ & $D-\mathrm{H} \cdots A$ \\
\hline $\mathrm{N}(3)-\mathrm{H}(3 \mathrm{~A}) \cdots \mathrm{O}(2)$ & $0.90(1)$ & $2.09(6)$ & $2.660(7)$ & $120(5)$ \\
\hline $\mathrm{N}(3)-\mathrm{H}(3 \mathrm{~B}) \cdots \mathrm{O}(1)^{\mathrm{i}}$ & $0.90(1)$ & $2.22(2)$ & $3.110(7)$ & $168(7)$ \\
\hline $\mathrm{N}(6)-\mathrm{H}(6 \mathrm{~A}) \cdots \mathrm{O}(4)$ & $0.90(1)$ & $1.99(5)$ & $2.663(7)$ & $130(6)$ \\
\hline $\mathrm{N}(6)-\mathrm{H}(6 \mathrm{~B}) \cdots \mathrm{O}(1)$ & $0.90(1)$ & $2.32(4)$ & $3.141(7)$ & $152(7)$ \\
\hline $\mathrm{N}(8)-\mathrm{H}(8 \mathrm{~A}) \cdots \mathrm{O}(1)^{\mathrm{ii}}$ & $0.90(1)$ & $2.17(2)$ & $3.030(7)$ & $161(6)$ \\
\hline $\mathrm{N}(8)-\mathrm{H}(8 \mathrm{~B}) \cdots \mathrm{O}(3)$ & $0.90(1)$ & $2.11(2)$ & $2.999(8)$ & $170(8)$ \\
\hline $\mathrm{O}(5)-\mathrm{H}(5 \mathrm{~A}) \cdots \mathrm{O}(3)^{\mathrm{iii}}$ & $0.85(1)$ & $2.07(4)$ & $2.890(8)$ & $160(10)$ \\
\hline $\mathrm{O}(5)-\mathrm{H}(5 \mathrm{~B}) \cdots \mathrm{O}(2)^{\mathrm{iv}}$ & $0.85(1)$ & $1.88(2)$ & $2.733(8)$ & $175(10)$ \\
\hline
\end{tabular}

Symmetry codes: i): $1+x, y, z$; ii): $-1-x,-1-y, 1-z$; iii) $-1 / 2+x, 1 / 2-y, 1 / 2+z$.

\section{RESULTS AND DISCUSSION}

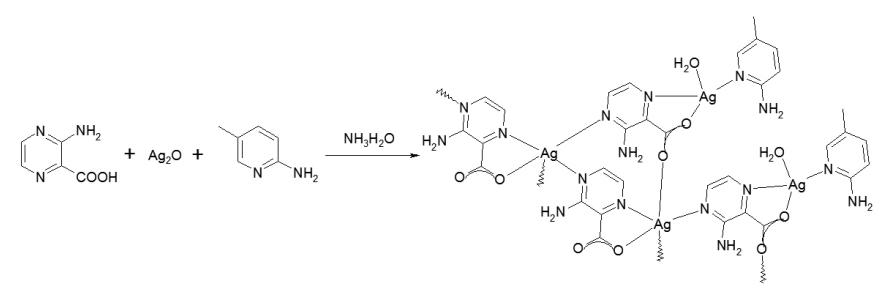


In the present complex, the $\mathrm{Ag}$ atom combines with the pyrazine $\mathrm{N}$ and carboxylate $\mathrm{O}$ atoms, instead of the amino $\mathrm{N}$ atom. This is due to the strain of the five-membered chelate ring is weaker than the four-membered chelate ring. Elemental analyses of the complex are in good agreement with expected values. Even though most silver complexes are sensitive to light, the present sample is very stable.

Infrared Spectrum: The weak and sharp absorption at $3287 \mathrm{~cm}^{-1}$ is resulted from the N-H vibrations of the amino groups. The $v_{(}(\mathrm{COO})$ is related to the strong band observed at $1613 \mathrm{~cm}^{-1}$, whereas the $v_{\mathrm{s}}(\mathrm{COO})$ is attributed to the medium band observed at $1376 \mathrm{~cm}^{-1}$. This gives rise to a $\Delta v$ of $237 \mathrm{~cm}^{-1}$ characteristic of bidentate coordination of the carboxylate group ${ }^{32}$.

Structure Description of the Complex: The molecular structure of the complex is shown in Figure 1. The smallest repeat unit contains a $\left[\mathrm{Ag}_{2}\left(\mathrm{~L}^{1}\right)_{2}\left(\mathrm{~L}^{2}\right)\right.$ $\left.\left(\mathrm{OH}_{2}\right)\right]$ moiety. The $\operatorname{Ag}(1) \cdots \mathrm{Ag}(2)$ distance is $7.490(2) \AA$. The $\mathrm{Ag}(1)$ atom is coordinated by three pyrazine $\mathrm{N}$ and two carboxylate $\mathrm{O}$ atoms from four $\mathrm{L}^{1}$ ligands, forming a square pyramidal coordination. The $\mathrm{Ag}$ atom deviates from the least squares basal plane defined by $\mathrm{O}(1), \mathrm{N}(1), \mathrm{N}(2 \mathrm{~A})$ and $\mathrm{O}(4 \mathrm{~B})$ by $0.232(1) \AA$. The cis and trans coordinate bond angles in the basal plane are $66.9(2)^{\circ}-102.3(2)^{\circ}$ and $150.3(2)^{\circ}-156.3(2)^{\circ}$, respectively. The bond angles between the apical donor atom $\mathrm{N}(5)$ and the basal donor atoms are in the range $84.1(2)^{\circ}-118.5(2)^{\circ}$. The deviation from the ideal values of square pyramidal geometry indicates the distortion of the coordination geometry. $\operatorname{The} \mathrm{Ag}(2)$ atom is coordinated by one pyrazine $\mathrm{N}$ and one carboxylate $\mathrm{O}$ atoms from a $\mathrm{L}^{1}$ ligand, one pyridine $\mathrm{N}$ atom from a $\mathrm{L}^{2}$ ligand, and one water $\mathrm{O}$ atom, forming a square planar geometry. The $\operatorname{Ag}(2)$ atom deviates from the least squares basal plane defined by the four donor atoms by $0.080(1) \AA$. The cis and trans coordinate bond angles defined by the donor atoms are $68.8(2)^{\circ}-106.8(2)^{\circ}$ and $158.6(2)$ ${ }^{\circ}-175.3(2)^{\circ}$, respectively. This also indicates that the square planar coordination is distorted. In addition, the distortion of the coordination can be observed from the bond lengths and angles related to the $\mathrm{Ag}$ atom. The $\mathrm{Ag}-\mathrm{O}$ bonds are much longer than the Ag-N bonds. Due to the strain created from the fivemembered chelated rings $\mathrm{Ag}(1)-\mathrm{N}(1)-\mathrm{C}(1)-\mathrm{C}(5)-\mathrm{O}(1)$ and $\mathrm{Ag}(2)-\mathrm{N}(4)-\mathrm{C}(8)-$ $\mathrm{C}(10)-\mathrm{O}(3)$, the angles $\mathrm{N}(1)-\mathrm{Ag}(1)-\mathrm{O}(1)$ and $\mathrm{N}(4)-\mathrm{Ag}(2)-\mathrm{O}(3)$ are much small. Yet, the Ag-O and Ag-N bonds are comparable to those observed in similar silver complexes ${ }^{33,34}$. In the crystal structure of the complex, Figures 2 and 3 , the dinuclear silver moieties are linked through $\mathrm{L}^{1}$ ligands, to form $1 \mathrm{D}$ chains along the $x$-axis direction. The chains are further linked through intermolecular hydrogen bonds (Table 3 ) in the $y$ - and $z$-axis directions, forming a 3D network. In addition, there are $\pi \cdots \pi$ interactions among the chains (Table 4 ).

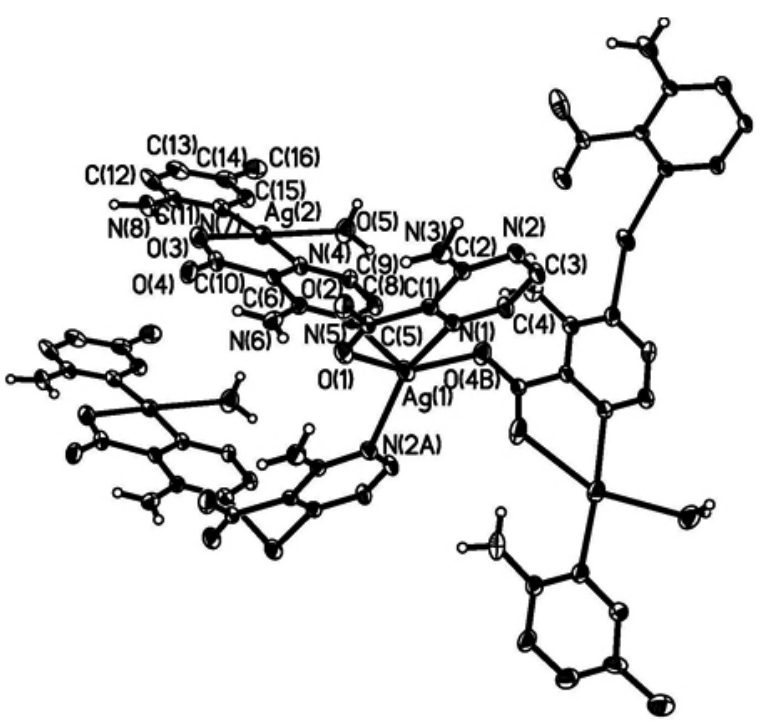
level.

Figure 1. Molecular structure of the silver complex with $30 \%$ probability

Cytotoxic Property: A549 lung cancer cells and L-02 human normal liver cell were used by MTT method to study the growth inhibitory effects of the complex. The IC values for the complex are $14.2 \pm 1.3 \mu \mathrm{M}$ for A549 and $57.3 \pm 3.7 \mu \mathrm{M}$ for L-02. As a comparison, the silver nitrate and cisplatin showed $\mathrm{IC}_{50}$ values of $8.7 \pm 0.9 \mu \mathrm{M}$ and $6.9 \pm 1.1 \mu \mathrm{M}$ for A549, and the ligands themselves showed no activity. Thus, the cytotoxic property of the complex is to some extent weak than the silver nitrate and cisplatin. However, considering the obvious side effects of the silver nitrate and cisplatin, the present silver complex is also a promising drug, which deserves further study.

Appendix A. Supplementary data

CCDC -1008308 for the complex contain the supplementary crystallographic data for this paper. These data can be obtained free of charge at http://www.ccdc.cam.ac.uk/const/retrieving.html or from the Cambridge Crystallographic Data Centre (CCDC), 12 Union Road, Cambridge CB2 1EZ, UK; fax: +44(0)1223-336033 or e-mail: deposit@ccdc.cam.ac.uk.

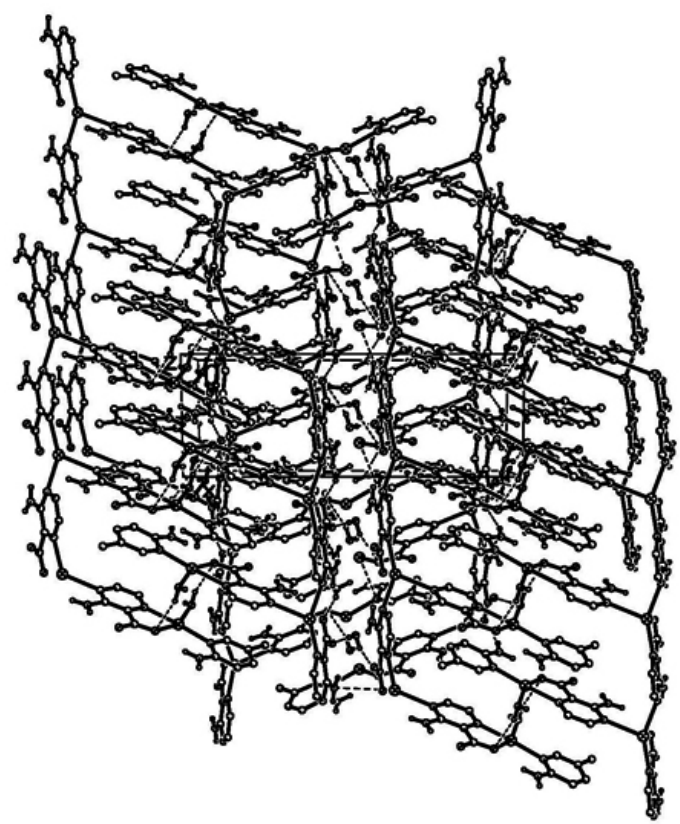

Figure 2. Molecular packing of the complex, viewed along the $z$ axis Hydrogen bonds are shown as dashed lines.

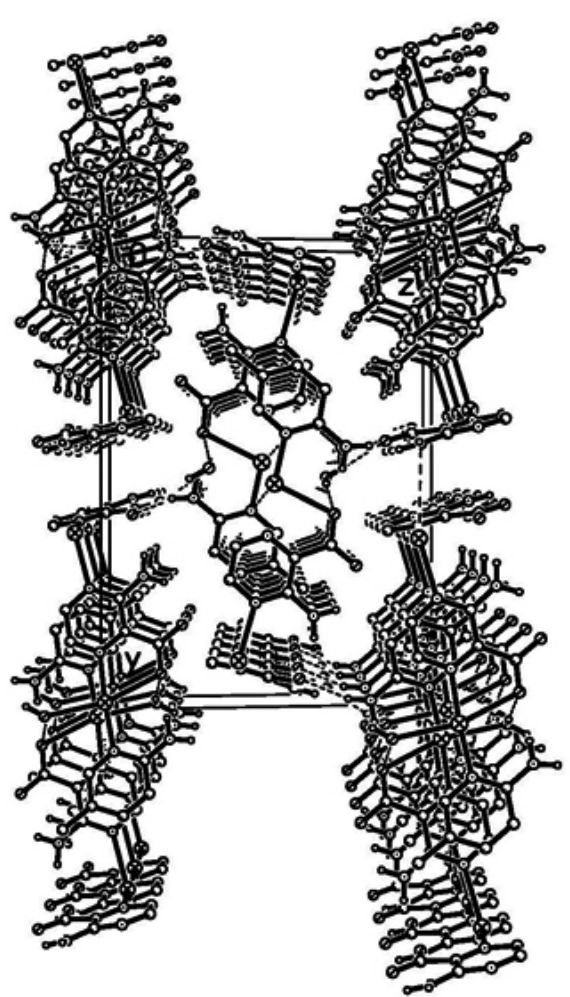

Figure 3. Molecular packing of the complex, viewed along the $x$ axis. Hydrogen bonds are shown as dashed lines. 
Table 4. Parameters between the planes for the complex.

\begin{tabular}{|c|c|c|c|c|c|}
\hline$C g$ & $\begin{array}{c}\text { Distance } \\
\text { between ring } \\
\text { centroids }(\AA)\end{array}$ & $\begin{array}{c}\text { Dihedral } \\
\text { angle }\left(^{(}\right)\end{array}$ & $\begin{array}{c}\text { Perpendicular } \\
\text { distance of } C g(\mathrm{I}) \text { on } \\
C g(\mathrm{~J})(\AA)\end{array}$ & $\begin{array}{c}\text { Perpendicular distance } \\
\text { of } C g(\mathrm{~J}) \text { on } C g(\mathrm{I})(\AA)\end{array}$ & Slippage \\
\hline$C g(1)-C g(1)^{\mathrm{iv}}$ & 4.318 & 0 & 3.342 & 3.342 & 2.734 \\
\hline$C g(1)-C g(4)^{\mathrm{iv}}$ & 3.950 & 3 & 3.413 & 3.401 & -3.245 \\
\hline$C g(2)-C g(3)^{\mathrm{v}}$ & 3.762 & 5 & -3.396 & 3.430 & 3.511 \\
\hline$C g(2)-C g(3)^{\mathrm{vi}}$ & 4.728 & 5 & 3.187 & 3.341 & -4.512 \\
\hline$C g(4)-C g(4)^{\mathrm{iv}}$ & 4.847 & 0 & 3.341 & -3.411 & \\
\hline$C g(4)-C g(5)^{\mathrm{vi}}$ & 4.894 & 65 & -3.611 & 3.430 & \\
\hline$C g(5)-C g(3)^{\mathrm{v}}$ & 3.992 & 6 & -3.228 & 3.355 & \\
\hline$C g(5)-C g(3)^{\mathrm{vi}}$ & 3.600 & 6 & & \\
\hline
\end{tabular}

Symmetry codes: iv): $1-x, 1-y,-z$; v): $-1-x,-y,-z$; vi): $-x,-y,-z . C g(1), C g(2), C g(3), C g(4)$ and $C g(5)$ are the centroids of $\mathrm{Ag}(1)-\mathrm{O}(1)-$ $\mathrm{C}(5)-\mathrm{C}(1)-\mathrm{N}(1), \quad \mathrm{Ag}(2)-\mathrm{N}(4)-\mathrm{C}(6)-\mathrm{C}(10)-\mathrm{O}(3), \quad \mathrm{N}(7)-\mathrm{C}(11)-\mathrm{C}(12)-\mathrm{C}(13)-\mathrm{C}(14)-\mathrm{C}(15), \quad \mathrm{N}(1)-\mathrm{C}(1)-\mathrm{C}(2)-\mathrm{N}(2)-\mathrm{C}(3)-\mathrm{C}(4)$ and $\mathrm{N}(4)-\mathrm{C}(6)-\mathrm{C}(7)-\mathrm{N}(5)-\mathrm{C}(8)-\mathrm{C}(9)$, respectively.

\section{REFERENCES}

1. S.H. Han, S.W. Lee, Polyhedron 31, 255, (2012).

2. K.-M. Park, E. Lee, C.S. Park, S.S. Lee, Inorg. Chem. 50, 12085, (2011).

3. M.O. Awaleh, A. Badia, F. Brisse, Cryst. Growth Des. 6, 2674, (2006).

4. D.R. Whitcomb, M. Rajeswaran, Polyhedron 25, 1747, (2006).

5. L. Zhang, Z.-L. You, Q.-Z. Jiao, Transition Met. Chem. 33, 573, (2008).

6. Z.-L. You, L. Zhang, D.-H. Shi, L.-L. Ni, Inorg. Chem. Commun. 12, 1231, (2009).

7. D.R. Whitcomb, M. Rajeswaran, Inorg. Chim. Acta 361, 1357, (2008).

8. R. Curran, J. Lenehan, M. McCann, K. Kavanagh, M. Devereux, D.A. Egan, G. Clifford, K. Keane, B.S. Creaven, V. McKee, Inorg. Chem. Commun. 10, 1149, (2007).

9. D.-F. Wang, Z.-H. Wang, B.-W. Lu, S.-F. Chen, T. Zhang, R.-B. Huang, L.-S. Zheng, J. Mol. Struct. 1059, 81, (2014).

10. F. Marandi, N. Hosseini, H. Krautscheid, D. Lassig, J. Lincke, M. Rafiee, Y.A. Asl, J. Mol. Struct. 1006, 324, (2011).

11. X. Liu, L. Li, Y.-Z. Yang, K.-L. Huang, Dalton Trans. 43, 4086, (2014).

12. X. Huang, Z.-F. Li, Q.-H. Jin, Q.-M. Qiu, Y.-Z. Cui, Q.-R. Yang, Polyhedron 65, 129, (2013).

13. G. Kaur, R.K. Verma, D.K. Rai, S.B. Rai, J. Lumin. 132, 1683, (2012).

14. F. Hackenberg, G. Lally, H. Muller-Bunz, F. Paradisi, D. Quaglia, W. Streciwilk, M. Tacke, Inorg. Chim. Acta 395, 135, (2013).

15. W.K. Liu, K. Bensdorf, A. Hagenbach, U. Abram, B. Niu, A. Mariappan, R. Gust, Eur. J. Med. Chem. 46, 5927, (2011).

16. S. Zartilas, S.K. Hadjikakou, N. Hadjiliadis, N. Kourkoumelis, L. Kyros, M. Kubicki, M. Baril, I.S. Butler, S. Karbabounas, J. Balzarini, Inorg. Chim. Acta 362, 1003, (2009).

17. R. Rowan, T. Tallon, A.M. Sheahan, R. Curran, M. McCann, K. Kavanagh, M. Devereux, V. McKee, Polyhedron 25, 1771, (2006).

18. A. Spira, D.S. Ettinger, New Eng. J. Med. 350, 379, (2004).

19. A. Jemal, R. Siegel, E. Ward, Y. Hao, J. Xu, T. Murray, M.J. Thun, $C A$ Cancer J. Clin. 58, 71, (2008).

20. X.-J. Tan, H.-Z. Liu, C.-Z. Ye, J.-F. Lou, Y. Liu, D.-X. Xing, S.-P. Li, S.-L. Liu, L.-Z. Song, Polyhedron 71, 119, (2014).

21. Y.-L. Li, Q.-P. Qin, Y.-F. An, Y.-C. Liu, G.-B. Huang, X.-J. Luo, G.-H Zhang, Inorg. Chem. Commun. 40, 73, (2014).

22. V. Gandin, M. Pellei, M. Marinelli, C. Marzano, A. Dolmella, M. Giorgetti, C. Santini, J. Inorg. Biochem. 129, 135, (2013).

23. H. Ptasiewicz-Bak, J. Leciejewicz, Pol. J. Chem. 73, 717, (1999).

24. R. Bouchene, S. Bouacida, F. Berrah, Acta Crystallogr. E69, m129, (2013).

25. S. Dehghanpour, K. Jahani, A. Mahmoudi, M. Babakhodaverdi, B. Notash, Inorg. Chem. Commun. 25, 79, (2012).

26. S. Gao, S.W. Ng, Acta Crystallogr. E66, m1466, (2010).

27. S. Gao, S.W. Ng, Acta Crystallogr. E66, m1223, (2010).

28. Z.-P. Deng, W. Kang, L.-H. Huo, H. Zhao, S. Gao, Dalton Trans. 39, 6276, (2010).

29. G.M. Sheldrick, SADABS Program for Empirical Absorption Correction of Area Detector, University of Göttingen, Germany, (1996).

30. G.M. Sheldrick, SHELXTL, Version 6.10, Software Reference Manual, Bruker Instrumentation, Madison, Wisconsin, USA, (2000).

31. Y. Zhao, W. Liu, Y. Zhou, X. Zhang, P.V. Murphy, Bioorg. Med. Chem. Lett. 20, 7540, (2010).

32. K. Nakamoto, Infrared and Raman Spectra of Inorganic and Coordination Compounds, Wiley, New York, (1986).

33. N. Wang, B. Li, J. Chem. Crystallogr. 41, 219, (2011).

34. D. Sun, Z.-H. Wei, C.-F. Yang, D.-F. Wang, N. Zhang, R.-B. Huang, L.-S. Zheng, CrystEngComm 13, 1591, (2011). 